\title{
Foliar Application of Saudi Desert Plants Extract Improved Some Mungbean Agronomic Traits Under Drought Stress
}

\author{
Fahad Mohammed Alghabari \\ Department of Arid Land Agriculture, Faculty of Meteorology, Environment \& Arid Land \\ Agriculture, King Abdulaziz University, Jeddah, Saudi Arabia
}

\begin{abstract}
To evaluate Saudi desert plants potential to promote mungbean growth under drought stress, a pot experiment was performed at field experimental station, King Abdulaziz University during 2016/2017 season. Drought stress was imposed by application of $40 \%$ and $60 \%$ field capacity (FC) levels. Pots with $100 \%$ field capacity were also maintained as control. Natural plant extracts of ten desert plants (Eucalyptus globulus, Azadirachta indica, Moringa oleifera Lam, Moringa peregrine Forssk., Tetraena simplex L., Simmondsia chinensis, Indigofera tinctoria, Dianella ensata, Emex spinosa, Ambrosia dumosa) were foliar applied prior to stress treatment application. Tap water treatment was used as control. Data for mungbean growth and pod characteristics were recorded. Drought stress decreased mungbean growth and severity of impact increased with lowering field capacity. The natural plant extract (NPE); NPE 9 (Dianella ensata) and NPE 11 (Ambrosia dumosa) favoured both plant growth 33\% and pod characteristics 11\%. The effect of NPE 6 (Tetraena simplex L.) and NPE 7 (Simmondsia chinensis) were significant for plant growth 21-24 cm while non-significant for pod characteristics under severe drought stress. On contrary, NPE 2 (Eucalyptus globulus) and NPE 3 (Azadirachta indica) effect was significant for mungbean pod characteristics $60 \%$ and non-significant for growth traits. The rest of the applied NPEs were non-significant for both growth and yield traits. The combination of NPE9 $\times$ FC-2, NPE6 $\times$ FC-2, NPE1 $1 \times$ FC-1 and NPE7 $\times$ FC-1 produced tallest plants $(29.33 \mathrm{~cm})$, maximum fresh biomass $(8.54 \mathrm{~g})$, dry biomass $(6.71 \mathrm{~g})$ and number of branches per plant (6.8). The combination of NPE2 $\times$ FC-2, NPE3 $\times$ FC-1, NPE9 $\times$ FC-1 and NPE11 $\times$ FC-3 produced maximum pods per plant $(4.2)$, pod length $(7 \mathrm{~cm})$, pod fresh weight $(5.4 \mathrm{~g})$ and dry weight $(4.5 \mathrm{~g})$ respectively. It's clear from the statistical analysis that mungbean performed better under medium stress level (FC-2) while NPE6, NPE7, NPE9 and NPE11 significantly stimulated plant growth under stressed environment. In conclusion, by application of Dianella ensata and Ambrosia dumosa, mungbean can be successfully grown under medium drought stress conditions.
\end{abstract}

Keywords: Plant extracts, Allelopathy, Water stress, Mungbean, Dianella ensata, Wild plants.

\section{Introduction}

The upcoming major challenge to world agriculture is to produce $70 \%$ more food for additional 2.3 billion peoples by 2050 . A the same time it also have to fight with increasing poverty and hunger, diminishing natural resources and adaptability to changing climate (FAO, 2009; Bourne, 2009). Crop productivity is not increasing with the same speed that is required to achieve food demands. This lower crop output is attributed to various abiotic stresses (Rosenzweig et al., 2014; Alghabari et al., 2015). In desert areas, aridity and low rain fall are chief contributors that limit crop productivity. This limitation in moisture supplies along with poor management of available resources needs special attention to 
resolve the issue. Cultivation of short duration crops with application of plant growth regulators is one of the options for drought tolerance in dry regions (Ramsey, et al., 2007).

Mungbean (Vigna radiate L.) is an annual summer crop belongs to Fabaceae family with short duration (70-90 days) and high nutritive value. Seed of mungbean comprise of $28 \%$ protein, $65 \%$ carbohydrates, $1.5 \%$ fat $4.5 \%$ fiber and 5.5\% ash (Kudre et al., 2013). It has multiple uses as human food, seeds, forages and broiler diet (Tang et al., 2014). It's mostly grown as cash crop due to fast growth habit, early maturation and useful for improving cropping pattern. Plant symbiotic relationship with soil bacteria to fix atmospheric nitrogen also improves soil fertility (Nabizade et al., 2011).

Mungbean is an important annual grain legume crop and widely cultivated both in irrigated and rainfed areas. Mungbean is used as whole grain or processed in making noodles, soup, porridge and snakes. It's an enriched source of protein, minerals and vitamins. Owing to its shorter growing period and fast growth habit, it is well fit in for an intercropping and as a cover crop. Very small amount of nutrients are required thus, it can be planted on poor agriculture soils. As, it is a leguminous crop, it harvest significant amount of atmospheric nitrogen and store it in its nodules (Tariq et al., 2007).

This nitrogen is later used by the subsequent crop after roots decay in the soil. Mungbean is also used as animal feed, particularly for sheep, goats and poultry. Due to its stress tolerance nature, it is mostly cultivated with lower moisture supplies. There are many studies that have already reported decreased plant growth and yield under drought stress (Fenta et al., 2014). This reduction in growth and yield is subjective to alterations in many plant morph physiological changes and impaired plant growth. The severity of drought stress is increasing day by day and it has been estimated that it will cause losses in global crop production of up to $30 \%$ by 2025 , compared with current yields (Zhang, 2011).

Over the years, climate change is an everincreasing phenomenon. Until now, negative effects of climatic variations have been observed on crop growth and yield viz., drought, salinity and heat stresses. Drought is undoubtedly most prevalent and damaging abiotic stress (Alghabari et al., 2015). Drought stress problem has been raised many folds over last two decades by anthropogenic factors, indiscriminate use, conveyance and application losses, inefficient irrigation methods and unbalanced fertilizers use. Molecular breeding and transgenic methods can be adopted to develop drought tolerant crops and to overcome this issue but, there are many ethical constraints and time issues attached to this approach. Owing to global pollution problem and increasing chemical prices, the use of artificial plant growth promoters is discouraged. In such scenario, the need for eco-friendly approaches have been overlooked.

Nature has blessed us with thousands of wild plants with exceptional potential for drought stress tolerance. These pants extracts exogenous application to field crops can improve growth, yield and tolerance level (Abbasi et al., 2009).

These wild plants are source of hundreds of biochemicals that have growth stimulatory nature. Experimental evidence for drought stress amelioration in field crops by the use of wild plant allelochemicals are lacking. But it did not negate their potential for stress regulation as their positive role in many biological stresses and disease management have already been explored successfully. Saudi desert is hub of plenteous wild flora whose 
allelochemicals potential needs to be discovered in detail. Declining fresh water resources, low annual rainfall, lack of water storing bodies and arid features of the region invites drought stress. This unwelcomed guest sometimes imprints unrecoverable damage to field crop especially if intercepted at germination or flowering stages. Mungbean is among those crops that are preferred due to their short duration and lower water requirements. Adoption of short duration drought tolerant mungbean still face severe drought cycles that minimizes fruit set and final grain yield.

Our objective was to explore positive role of desert plants for drought stress management in mungbean crop. The effect of foliar applied plants (Eucalyptus globulus, Azadirachta indica, Moringa oleifera Lam, Moringa peregrine Forssk., Tetraena simplex L., Simmondsia chinensis, Indigofera tinctoria, Dianella ensata, Emex spinosa, Ambrosia dumosa) extracts will be evaluated on biomass $(\mathrm{g} / \mathrm{kg})$ and some agronomic traits of mungbean crop under water stress levels.

\section{Materials and Methods}

A pot experiment was conducted at Hada AlSham Agricultural Research Station during 2016. Ten NPE were used along with the control. Water stress was applied as $40 \%, 60 \%$ and $100 \%$ of field capacity (FC). Randomized complete block design was used with factorial arrangements. Each treatment was replicated thrice. A total of 99 pots were used in this experiment. The used NPE, FC and sequence of treatments are presented (Table 1).

\section{Soil preparation}

In the first week of February the soil of agriculture fields of Hada Al-Sham was mixed with organic amendment (farmyard manure) by a 50:50 ratios (half soil and half organic amendment) to increase the soil physiochemical and biological properties. After that pots were filled by adding $5 \mathrm{~kg}$ soil in each pot. Water was applied in equal amount to attain moisture content at FC level in each pot. Field capacity of soil was determined by gravimetric method. The $60 \%$ and $40 \%$ of FC were used as stress treatments while $100 \%$ was considered as control (non-stressed). On 15 February the mungbean crop was sowed in the pots ( 5 seed in each pots). Pots height were 26 $\mathrm{cm}$ with a diameter of $12 \mathrm{~cm}$. seeds were sown at $5 \mathrm{~cm}$ distance.

\section{Crop husbandry}

After 15 days of germination of mung bean seeds, the plant population was set to 3 plants per pot. The NPK was mixed with water before application to each pot. The NPK was applied at a rate of 45:80:50 kg per hectare and dose was calculated for an individual pot before application. Fertilizers were applied as water solutions for approximately $2 \mathrm{~g}$ per pot in three splits. Level of field capacities were adjusted by maintaining the amount of water applied to each pot. The field capacity of the soil was measured by knowing the saturation point of the soil. Half of this saturation point was considered as field capacity. The $40 \%$ and $60 \%$ were calculated from the $100 \%$ of the field capacity and were considered as medium and severe stress levels.

\section{Extract preparation}

Water extract of ten wild plants were prepared. To take the extract from natural plants, I. $5 \mathrm{~kg}$ air dried biomass of each plant was fine chopped and soaked in 5 liter water for 30 minutes and then it was boiled for 3 hours at $100{ }^{\circ} \mathrm{C}$ until the concentrate solution was obtained. The extract was cooled and saved in plastic bottles to preserve from contamination and future use (Yasmeen et al., 2012).

\section{Treatment application}

After one week of adjusting field capacities the plants extracts were applied (exogenous 
spray) to each replication by diluting the extract 10 times. Three doses of plant extracts were applied to 20, 40 and 60 days of crop. Pots were harvested at maturity and following parameters were measured.

\section{Data measurement}

At harvesting these traits were measured. Plant height $(\mathrm{cm})$, pod length $(\mathrm{cm})$, number of branches per plant and number of pods per plant, plant fresh weight (g), plant dry weight $(\mathrm{g})$, pod fresh weight $(\mathrm{g})$ and pod dry weight (g). All these traits were taken from the three plants per pot.

\section{Statistical Analysis}

Factorial experiment in randomized complete block design was used to analyses the data. Analysis of variance was performed by using SAS software. Treatment means were compared by using LSD test to estimate their significance.

\section{Results}

\section{Agronomic Traits}

Effect of natural plant extracts (NPE) were studied on mungbean agronomic characteristics viz., plant height, number of branches per plant and fresh and dry biomass plant weight. Water stress significantly affected plant height, number of branches per plant and plant dry weight while no effect was recorded on plant fresh weight. Significant effect of NPEs and their interaction NPE $\times$ FC was highly significant for all plant growth traits except for number of branches per plant for NPE (Table 2).

A gradual reduction in plant height and dry weight was prominent with the increasing stress levels. Minimum growth was attained at severe drought stress level. Plant water extracts significantly improved mung bean growth but the effect was variable with the changing plant species and studied growth character. The combination of NPE9 $\times$ FC-2, NPE6 $\times$ FC-2, NPE06 $\times$ FC-1 and NPE7 $\times$ FC-1 produced longest plants, maximum fresh biomass, dry biomass and number of branches per plant. It's clear from the statistical analysis that mungbean performed better under medium stress level (FC-2) while NPE6, NPE7, NPE9 and NPE11 significantly stimulated plant growth under stressed environment.

\section{Pod Characteristics}

Effect of drought stress, NPE and their interaction FC $\times$ NPE were studied on pod characteristics i.e., number of pods per plant, pod length, pod fresh and dry weight. Effect of FC was significant for number of pods per plant, pod fresh weight and pod dry weight. However, pod length was unaffected by changing drought stress levels. Natural plant extract significantly improved pod fresh and dry weight, however, number of pods per plant and pod length was unaffected. The interaction of NPE $\times$ FC were highly significant for number of pods per plant, pod fresh and dry weight, while non-significant effect was calculated for pod length (Table 3).

All pod characteristics were superior for unstressed pods over stressed except for pod dry weight. Medium stress level reported in between results of high and low water stress. Plant water extracts mostly improved mung bean pod characteristics. Some NPEs also produced negative effects for both plant and pod growth traits over control. The combination of FC- $2 \times$ NPE2, FC- $1 \times$ NPE3, FC-1 $\times$ NPE9 and FC-3 $\times$ NPE11 produced maximum pods per plant, pod length, pod fresh and dry weight respectively. The effect of NPEs were more pronounced for pod length and fresh weight where almost similar values were produced for most of the applied extracts at all three studied FC. An approximately 50\% lower number of pods per plant were noticed 
at half of the water supply. Apparently, NPE decreased pod dry weight at medium stress while improved at severe water stress.

The natural plant extract; NPE 9 (Dianella ensata) and NPE 11 (Ambrosia dumosa) favoured both plant growth and pod characteristics. The effect of NPE 6 (Tetraena simplex L.) and NPE 7 (Simmondsia chinensis) were significant for plant growth while nonsignificant for pod characteristics. On contrary, NPE 2 (Eucalyptus globulus) and NPE 3 (Azadirachta indica) effect was significant for mungbean pod characteristics and non-significant for agronomic traits. The rest of the applied NPEs were non-significant for both growth and yield traits.

Table 1. Tabulated presentation of natural plant extract (NPE) and field capacity (FC) treatment.

\begin{tabular}{|c|c|c|c|}
\hline Sr. No & Treatments & Common name & Botanical name \\
\hline \multicolumn{4}{|c|}{ Plant water extracts } \\
\hline 1 & NPE1 & Control & Water spray \\
\hline 2 & NPE2 & Eucalyptus & Eucalyptus globulus \\
\hline 3 & NPE3 & Neem & Azadirachta indica \\
\hline 4 & NPE4 & drumstick tree & Moringa oleifera Lam \\
\hline 5 & NPE5 & Ben tree & Moringa peregrine Forssk \\
\hline 6 & NPE6 & Hureim & Tetraena simplex $\mathrm{L}$ \\
\hline 7 & NPE7 & Jojoba & Simmondsia chinensis \\
\hline 8 & NPE8 & Guatemalan indigo & Indigofera tinctoria \\
\hline 9 & NPE9 & Flax lily & Dianella ensata \\
\hline 10 & NPE10 & Devil's thorn & Emex spinosa \\
\hline \multirow[t]{2}{*}{11} & NPE11 & burro-weed & Ambrosia dumosa \\
\hline & Water stress & & \\
\hline 1 & FC1 & $100 \%$ & No stress \\
\hline 2 & FC2 & $60 \%$ & Medium stress \\
\hline 3 & FC3 & $40 \%$ & Severe stress \\
\hline
\end{tabular}

Table 2. Effect of foliar applied natural plant extracts (NPEs) and water stress (FC) on mungbean growth characteristics.

\begin{tabular}{|c|c|c|c|c|c|c|c|c|c|}
\hline \multirow{2}{*}{$\begin{array}{c}\text { Plant } \\
\text { extracts }\end{array}$} & \multicolumn{3}{|c|}{ Plant height (cm) } & \multicolumn{3}{|c|}{ Plant fresh weight (g) } & \multicolumn{3}{|c|}{ Plant dry weight (g) } \\
\hline & FC-1 ${ }^{\mathrm{A}}$ & FC-2 & FC-3 & FC-1 & FC-2 & FC-3 & FC-1 & FC-2 & FC-3 \\
\hline NPE 1 & $28.66 \mathrm{ab}$ & $24.66 \mathrm{~d}-\mathrm{h}$ & 18.311 & $7.72 \mathrm{a}-\mathrm{e}$ & $7.13 \mathrm{~b}-\mathrm{i}$ & $5.56 \mathrm{k}$ & $5.81 \mathrm{a}-\mathrm{d}$ & $4.52 \mathrm{~g}-1$ & 3.651 \\
\hline NPE 2 & $23.67 \mathrm{f}-\mathrm{j}$ & $26.09 \mathrm{c}-\mathrm{e}$ & $19.05 \mathrm{kl}$ & 7.91 a-e & $7.22 \mathrm{~b}-\mathrm{i}$ & $7.13 \mathrm{~b}-\mathrm{i}$ & $4.12 \mathrm{i}-1$ & $5.33 \mathrm{~b}-\mathrm{g}$ & 3.641 \\
\hline NPE 3 & $24.00 \mathrm{e}-\mathrm{i}$ & $23.33 \mathrm{~g}-\mathrm{j}$ & $22.03 \mathrm{ij}$ & $7.63 \mathrm{a}-\mathrm{f}$ & $7.55 \mathrm{a}-\mathrm{f}$ & $6.17 \mathrm{~h}-\mathrm{k}$ & $5.96 \mathrm{a}-\mathrm{c}$ & $5.32 \mathrm{~b}-\mathrm{g}$ & $3.71 \mathrm{kl}$ \\
\hline NPE 4 & $27.00 \mathrm{a}-\mathrm{d}$ & $24.66 \mathrm{~d}-\mathrm{h}$ & $23.69 \mathrm{f}-\mathrm{j}$ & $8.32 \mathrm{ab}$ & $8.01 \mathrm{a}-\mathrm{d}$ & $7.11 \mathrm{~b}-\mathrm{i}$ & $4.93 \mathrm{~d}-\mathrm{i}$ & $5.66 \mathrm{~b}-\mathrm{e}$ & $4.52 \mathrm{~g}-1$ \\
\hline NPE 5 & $23.33 \mathrm{~g}-\mathrm{j}$ & $25.33 \mathrm{~d}-\mathrm{g}$ & $19.33 \mathrm{kl}$ & $8.15 \mathrm{a}-\mathrm{c}$ & $7.32 \mathrm{a}-\mathrm{h}$ & $6.87 \mathrm{~d}-\mathrm{j}$ & $5.38 \mathrm{~b}-\mathrm{g}$ & $4.23 \mathrm{~h}-1$ & $4.06 \mathrm{i}-1$ \\
\hline NPE 6 & $26.01 \mathrm{c}-\mathrm{f}$ & $25.33 \mathrm{~d}-\mathrm{g}$ & $24.32 \mathrm{e}-\mathrm{i}$ & $7.83 \mathrm{a}-\mathrm{e}$ & $8.54 \mathrm{a}$ & $6.77 \mathrm{e}-\mathrm{k}$ & $6.16 \mathrm{ab}$ & $4.77 \mathrm{e}-\mathrm{j}$ & 3.571 \\
\hline NPE 7 & $26.33 \mathrm{~b}-\mathrm{e}$ & $22.66 \mathrm{~h}-\mathrm{j}$ & $21.36 \mathrm{jk}$ & $6.76 \mathrm{e}-\mathrm{k}$ & $7.06 \mathrm{c}-\mathrm{i}$ & $6.30 \mathrm{~g}-\mathrm{k}$ & $4.93 \mathrm{~d}-\mathrm{i}$ & $3.72 \mathrm{kl}$ & $3.94 \mathrm{j}-1$ \\
\hline NPE 8 & $25.00 \mathrm{~d}-\mathrm{h}$ & $25.33 \mathrm{~d}-\mathrm{g}$ & $21.32 \mathrm{jk}$ & $7.43 \mathrm{a}-\mathrm{g}$ & $7.43 \mathrm{a}-\mathrm{g}$ & $6.45 \mathrm{f}-\mathrm{k}$ & $3.84 \mathrm{j}-1$ & 4.06 il & $3.73 \mathrm{kl}$ \\
\hline NPE 9 & $23.66 \mathrm{f}-\mathrm{j}$ & $29.33 \mathrm{a}$ & $23.56 \mathrm{~g}-\mathrm{j}$ & 7.82 a-e & $6.90 \mathrm{~d}-\mathrm{j}$ & $5.71 \mathrm{jk}$ & $5.12 \mathrm{c}-\mathrm{h}$ & $5.41 \mathrm{~b}-\mathrm{g}$ & $3.77 \mathrm{kl}$ \\
\hline NPE 10 & $28.00 \mathrm{a}-\mathrm{c}$ & $23.67 \mathrm{f}-\mathrm{j}$ & $23.37 \mathrm{~g}-\mathrm{j}$ & $6.67 \mathrm{e}-\mathrm{k}$ & 7.83 a-e & $6.05 \mathrm{i}-\mathrm{k}$ & $5.56 b-f$ & $5.16 \mathrm{c}-\mathrm{h}$ & 3.561 \\
\hline NPE 11 & $24.02 \mathrm{e}-\mathrm{i}$ & $24.62 \mathrm{e}-\mathrm{h}$ & $24.39 \mathrm{e}-\mathrm{i}$ & $8.53 \mathrm{a}$ & $7.55 \mathrm{a}-\mathrm{f}$ & $6.75 \mathrm{e}-\mathrm{k}$ & $6.71 \mathrm{a}$ & $4.65 \mathrm{f}-\mathrm{k}$ & 3.671 \\
\hline NPE & $* *$ & & & $*$ & & & $* *$ & & \\
\hline $\mathrm{FC}$ & $*$ & & & $\mathrm{Ns}$ & & & $* *$ & & \\
\hline NPE $\times F C$ & $* *$ & & & $* *$ & & & $* *$ & & \\
\hline LSD & 2.37 & & & 1.24 & & & 0.98 & & \\
\hline $\mathrm{CV}$ & 6.08 & & & 10.55 & & & 12.92 & & \\
\hline
\end{tabular}

${ }^{\mathrm{A}}$; figures differing in letters are statistically significant at $\mathrm{p} \leq 0.05, *$; significant at $\mathrm{p} \leq 0.05$, **; significant at $\mathrm{p} \leq 0.01$, ns; nonsignificant, LSD; least significant difference and CV; coefficient of variation. 
Table 3. Mungbean plant number of branches and pod characteristics as affected by drought stress (FC) and natural plant extract (NPE) foliar application.

\begin{tabular}{|c|c|c|c|c|c|c|c|c|c|c|c|c|c|c|c|}
\hline \multirow{2}{*}{$\begin{array}{c}\text { Plant } \\
\text { extract }\end{array}$} & \multicolumn{3}{|c|}{$\begin{array}{c}\text { Number of branches } \\
\text { per plant }\end{array}$} & \multicolumn{3}{|c|}{ Pods per plant } & \multicolumn{3}{|c|}{ Pod length $(\mathrm{cm})$} & \multicolumn{3}{|c|}{$\begin{array}{l}\text { Pods fresh weight } \\
\text { (g) }\end{array}$} & \multicolumn{3}{|c|}{ Pods dry weight (g) } \\
\hline & FC-1 & FC-2 & FC-3 & FC-1 & FC-2 & FC-3 & FC-1 & FC-2 & FC-3 & FC-1 & FC-2 & FC-3 & FC-1 & FC-2 & FC-3 \\
\hline NPE 1 & 5.0 & 5.6 & 4.1 & 2.6 & 2.3 & 2.1 & 6.3 & 5.0 & 5.0 & 4.7 & 4.3 & 3.8 & 2.7 & 1.6 & 4.0 \\
\hline NPE 2 & 5.1 & 4.3 & 4.3 & 2.1 & 4.0 & 1.6 & 5.6 & 6.0 & 5.0 & 4.3 & 4.3 & 4.0 & 2.0 & 1.9 & 4.0 \\
\hline NPE 3 & 5.3 & 5.0 & 3.6 & 2.6 & 2.3 & 2.0 & 7.0 & 6.1 & 5.1 & 4.3 & 4.1 & 3.8 & 2.1 & 1.7 & 4.2 \\
\hline NPE 4 & 4.3 & 4.6 & 4.1 & 2.6 & 3.0 & 2.1 & 5.6 & 6.0 & 6.0 & 4.1 & 3.9 & 3.7 & 2.3 & 1.8 & 3.9 \\
\hline NPE 5 & 4.0 & 5.0 & 5.3 & 2.3 & 2.6 & 1.6 & 6.3 & 6.1 & 5.1 & 5.0 & 4.3 & 3.9 & 3.3 & 2.0 & 4.1 \\
\hline NPE 6 & 6.0 & 5.0 & 4.6 & 3.6 & 2.3 & 1.6 & 5.3 & 6.0 & 5.6 & 5.1 & 3.7 & 3.5 & 3.3 & 2.0 & 3.9 \\
\hline NPE 7 & 6.6 & 4.0 & 3.6 & 2.6 & 2.3 & 2.0 & 6.0 & 6.0 & 5.6 & 4.3 & 4.1 & 3.4 & 2.5 & 2.2 & 4.0 \\
\hline NPE 8 & 5.3 & 4.3 & 3.3 & 2.1 & 2.6 & 1.6 & 6.0 & 6.3 & 5.6 & 4.4 & 3.9 & 3.4 & 2.4 & 2.0 & 3.4 \\
\hline NPE 9 & 4.3 & 3.3 & 3.0 & 2.6 & 2.1 & 2.0 & 6.1 & 5.6 & 6.1 & 5.2 & 4.3 & 3.5 & 3.3 & 2.2 & 3.5 \\
\hline NPE 10 & 4.3 & 3.3 & 4.3 & 3.3 & 2.0 & 1.6 & 6.0 & 6.3 & 5.6 & 4.2 & 4.1 & 3.1 & 2.2 & 2.3 & 3.1 \\
\hline NPE 11 & 6.0 & 4.0 & 4.1 & 2.3 & 2.0 & 2.1 & 6.6 & 6.3 & 5.7 & 4.9 & 4.4 & 4.1 & 2.5 & 2.6 & 4.4 \\
\hline NPE & NS & & & $*$ & & & $*$ & & & $* *$ & & & $*$ & & \\
\hline $\mathrm{FC}$ & $*$ & & & $*$ & & & $*$ & & & $*$ & & & $* *$ & & \\
\hline $\mathrm{NPE} \times \mathrm{FC}$ & NS & & & $* *$ & & & $* *$ & & & $*$ & & & $*$ & & \\
\hline LSD & 0.92 & & & 0.32 & & & 1.05 & & & 0.57 & & & 0.49 & & \\
\hline $\mathrm{CV}$ & 3.5 & & & 4.8 & & & 6.5 & & & 8.2 & & & 7.1 & & \\
\hline
\end{tabular}

*; significant at $\mathrm{p} \leq 0.05, * *$; significant at $\mathrm{p} \leq 0.01$, ns; non-significant, LSD; least significant difference and CV; coefficient of variation.

\section{Discussion}

Drought is the most complex and devastating threat to field crops that has multiple damaging effects. Alteration in leaf morphology, physiology, plant growth and grain development were the common morpho-physiological changes in plants. Disturbed osmotic balance, stomatal conductance, impaired photosynthesis, membrane electron transport rate and increased evapotranspiration level limit growth and development thus reduced final yield (Allahmoradi et al., 2011; Srivalli et al., 2003). Crop planted under arid land conditions encounter water deficit stress at various developmental stages.

The effect of these six natural plants (Dianella ensata, Ambrosia dumosa, Simmondsia chinensis, Eucalyptus globulus, Tetraena simplex L., Azadirachta indica) extracts were significant for mungbean growth and yield characteristics. Allelochemicals may be present in any part of the plant. They may be found in the leaves, roots, stem, flower or fruit. Their presence in the root rhizosphere has also been reported (Bertin, et al., 2003). Both inhibitory and regulatory effect of allelochemicals has been documented in both field and pot trials (Ihsan et al., 2015). Allelopathy is emerging as new branch of agriculture because its positive role in pest management and abiotic stress regulation is not only cost effective and cheaper but also environment friendly. Water leachates of wild plant reduced drought impact on plant growth and yield by positively regulating moisture supplies, nutrient availability and photosynthesis. Varying degree of stimulatory and inhibitory effect of wild plant water leachates have been reported previously 
(Chen et al 2008; Cornes 2005). Ihsan et al (2015) have advocated the commercial utilization of these allelochemicals based on their stimulatory and inhibitory activity for specific crops. Furthermore these findings may contribute for drought regulation in organic farming.

Allelochemicals are secondary metabolites and have no direct roles in primary metabolism, they are appeared to be involved in defense against abiotic stresses (Wahid and Ghazanfar, 2006), although the exact mechanisms of their beneficial roles are still elusive. Han et al. (2008) assayed aqueous extract of rhizome, leaf, and stem of ginger (Zingiber officinale L. ) at 10-80 g L- 1, which enhances the drought resistance in soybean ( Glycine max L.) seeds by stimulating the water uptake with a course of time that decrease with increased concentration of extract. Low concentration of caffeic acid stimulated the nitrate uptake (Abenavoli et al., 2001). Foliar application of diluted sorghum extract dilutions on maize under drought stress at vegetative stage manifested that low concentrations enhanced the morphological as well as biochemical attributes. Photosynthetic pigments increased free amino acids and anthocyanins, which acclimatized the maize plants to drought at $0.25-0.75 \mathrm{ml} \mathrm{L}-1$ of sorghum extract (Maqbool, 2010). Elevated levels of linalyl acetate, trans-sabinene hydrate and transsabinene hydrate acetate in $\mathrm{O}$. dayi; 1, 8cineole, camphor, germacrene $\mathrm{D}$, camphene, para-cymene, jasmine ketolactone and aTujene in A. sieberi; ethyl cinnamate, borneol and piperitone in A. judaica were observed under drought stress (Friedjung et al., 2013). These allelochemicals improved plant drought resistance by acting as osmoregulators and signaling agents. Thus, caused a reduction in reactive oxygen species production and photorespiration. Alternatively, improved photosynthesis and nutrient uptake that ultimately helped in drought stress tolerance in plants.

The improved mungbean drought tolerance was due to Dianella ensata, Ambrosia dumosa, Tetraena simplex L., Simmondsia chinensis, Eucalyptus globulus and Azadirachta indica water extract application that increased leaf osmotic potential, water uptake, photo assimilation and by activating antioxidant defense system. The identification of allelochemicals responsible for this drought tolerance needs bioassay of these wild plants extract that will be carefully examined in future studies.

\section{Conclusion}

Positive role of wild plant (Dianella ensata and Ambrosia dumosa) water leachates on mungbean growth and stress regulation helped to mitigate adverse effects of drought on plant physiological and agronomic attributes, thus; efficient water management resulted in higher grain yield. Furthermore screening of most promising wild plant allelochemicals can be quantified using reverse phase high performance liquid chromatography and promoted for commercial production and utilization in drought regulation.

\section{Acknowledgement}

This project was funded by the Deanship of Scientific Research (DSR) at King Abdulaziz University, Jeddah, under grant no. G-185 / 155 / 37. The authors, therefore, acknowledge with thanks DSR for technical and financial support.

\section{Reference}

Abbasi, M. K., Mushtaq, A., and Tahir, M. M. (2009). Cumulative effects of white clover residues on the changes in soil properties, nutrient uptake, growth and yield of maize crop in the sub-humid hilly region of Azad Jammu and Kashmir, Pakistan. African Journal of Biotechnology, 8 (10).

Abenavoli, M. R., Santis, C.D., Sidari, M., Sorgona, A., Badiani, M., Cacco, G. (2001). Influence of coumarin on 
the net nitrate uptake in Durum wheat. New Phytol, 150: 619-627.

Alghabari, F., Ihsan, M. Z., Hussain, S., Aishia, G., \& Daur, I. (2015). Effect of Rht alleles on wheat grain yield and quality under high temperature and drought stress during booting and anthesis. Environmental Science and Pollution Research, 22 (20): 15506-15515.

Allahmoradi, P., Ghobadi, M., Taherabadi, S. and Taherabadi, S. (2011). Physiological aspects of mungbean (Vigna radiata L.) in response to drought stress. In International conference on food engineering and biotechnology, IPCBEE, Volume 9. pp. 272-275.

Bertin, C., Yang, X. and Weston, L.A. (2003). The role of root exudates and allelochemicals in the rhizosphere. Plant and Soil, 256, 67-83.

Bourne, J. (2009). The global food crisis - The end of plenty. National Geographer, 26-59.

Chen, X., Hu, F. and Kong, C. (2008). Varietal improvement in rice allelopathy. Allelopathy, $\mathrm{J}$ (22): 379-384.

Cornes, D. (2005). Callisto: a very successful maize herbicide inspired by allelochemistry. In Proceedings of Fourth World Congress on Allelopathy, Wagga Wagga, NSW, Australia. http://www. regional. org. au/au/allelopathy/2005/2/7/2636_cornesd. htm. Accessed: April, Volume 2. p. 2008.

FAO, U. (2009). How to Feed the World in 2050. In Rome: High-Level Expert Forum.

Fenta, B. A., Beebe, S. E., Kunert, K. J., Burridge, J. D., Barlow, K. M., Lynch, J. P., and Foyer, C. H. (2014). Field phenotyping of soybean roots for drought stress tolerance. Agronomy, 4 (3): 418-435.

Friedjung, A.Y., Choudhary, S.P., Dudai, N. and Rachmilevitch, S. (2013). Physiological conjunction of allelochemicals and desert plants. PloS one, 8 (12): p.e8158.

Han, C. M., Pan, K. W., Wu, N., Wang, J. C. and Li, W. (2008) Allelopathic effect of ginger on seed germination and seedling growth of soybean and chive. Hort Science, 116: 330-336.

Ihsan, M.Z., Khaliq, A., Mahmood, A., Naeem, M., ElNakhlawy, F. and Alghabari, F. (2015). Field evaluation of allelopathic plant extracts alongside herbicides on weed management indices and weed-crop regression analysis in maize. Weed Biology and Management. 15(2): 78-86.

Kudre, T.G., Benjakul, S. and Kishimura, H. (2013). Comparative study on chemical compositions and properties of protein isolates from mung bean, black bean and bambara groundnut. Journal of the Science of Food and Agriculture, 93: 2429-2436.

Maqbool, N. (2010) Exploring the role of sorgaab in improving water stress tolerance in maize at germination and vegetative growth stages. M. Phil Thesis submitted to Department of Botany, University of Agriculture, Faisalabad, Pakistan

Nabizade, M., Nejad, T.S. and Mojadam, M. (2011). Effect of irrigation on the yield of mungbean cultivars Maryam Nabizade1, Tayeb Saki Nejad2, Mani Mojadam3. Journal of American Science, 7 (7).

Ramsey, S., Subbia, A., Bass, S. and Juergens, I. (2007). Livelihood adaptation to climate variability and change in drought-prone areas of Bangladesh. Asian Disaster Preparedness Center Food and Agriculture Organization of the United Nations.

Rosenzweig, C., Elliott, J., Deryng, D., Ruane, A.C., Müller, C., Arneth, A., Boote, K.J., Folberth, C., Glotter, M. and Khabarov, N. (2014). Assessing agricultural risks of climate change in the 21 st century in a global gridded crop model intercomparison. Proceedings of the National Academy of Sciences, 111: 3268-3273.

Srivalli, B., Sharma, G., and Khanna-Chopra, R. (2003). Antioxidative defense system in an upland rice cultivar subjected to increasing intensity of water stress followed by recovery. Physiologia Plantarum, 119: 503-512.

Tang, D., Dong, Y., Ren, H., Li, L. and He, C. (2014). A review of phytochemistry, metabolite changes, and medicinal uses of the common food mung bean and its sprouts (Vigna radiata). Chemistry Central Journal, 8: 4.

Tariq, S., Ali, S., \& Ijaz, S. S. (2007). Improving Nitrogen Fixation Capacity and Yield of Mungbean and Mashbean by Phosphorous Management in Pothowar. Sarhad Journal of Agriculture, 23 (4): 1027.

Wahid, A. and Ghazanfar, A. (2006). Possible involvement of some secondary metabolites in salt tolerance of sugarcane. Journal Plant Physiology, 163:723-730.

Yasmeen, A., Basra, S.M.A., Ahmad, R. and Wahid, A. (2012). Performance of late sown wheat in response to foliar application of Moringa oleifera Lam. leaf extract. Chil J Agric Res, 72: 92-97.

Zhang, J. (2011). China's success in increasing per capita food production. Journal of Experimental Botany, 62 (11): 3707-3711. 


\section{استخدام مستخلصات النباتات الصحراوية لتحسين بعض الصفات النباتية لمحصول فول \\ المونج تحت ظروف الإجهاد المائي في المملكة العربية السعودية فهر محمد الغباري \\ قسم زراعة المناطق الجافة، كلية الأرصاد والبيئة وزراعة المناطق الجافة، جامعة الملك عبدالعزيز، المدلكة العربية السعودية}

المستخلص. لقد تم إجراء تجربة باستعمال المراكن داخل محطة الأبحاث الحقلية بجامعة الملك

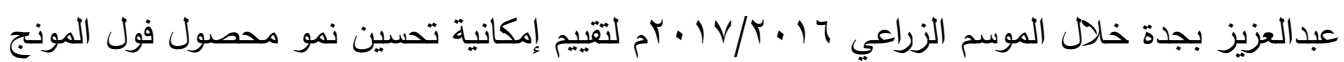
تحت ظروف الإجهاد المائي عن طريق الدور الكامن للنباتات الصحراوية في المملكة العربية السعودية.

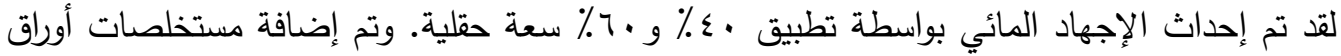

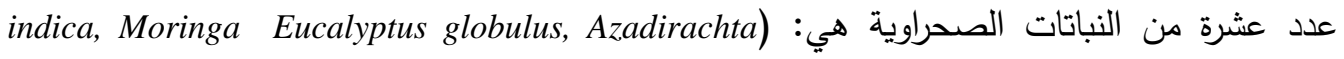
oleifera Lam, Moringa peregrine Forssk., Tetraena simplex L., Simmondsia chinensis, (Indigoferia tinctoria, Dianella ensata, Emexspinosa, Ambrosia dumosa) المراكن قبل البدء باستعمال الجهد المائي. بالإضافة إلى ذلك فهناك المعاملة الثاهد حيث تم ري

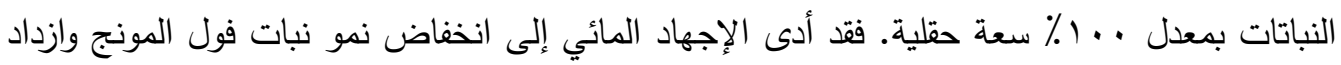

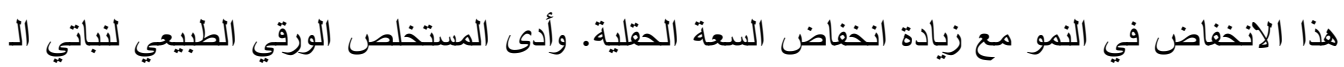
Ambrosia dumosa و Dianellaensata

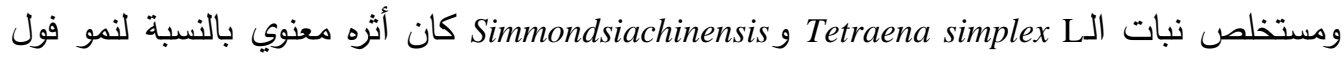
المونج، بينما أثر مستخلص نبات الـ Eucalyptus globulus and Azadirachtaindica معنويًا في

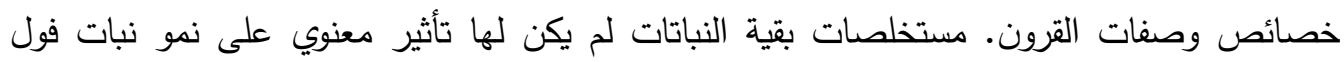
المونج ولا على صفات الإنتاج. وكان لتفاعل مستخلصات بعض النباتات آثات دئار معنوية فيما يتعلق بزيادة

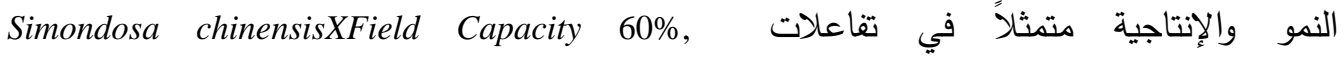
EmexspinosaXField Capacity 60\%, Ambrosia dumosa X Field Capacity 60\%, Indigoferia tinctoria X Field Capacity 40\% حيث أعطت هذه التفاعلات أطول النباتات وأعلى وزن للكتلة

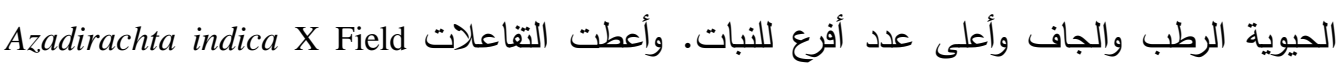
capacity 60\%, Moringa oleifera LamX Field capacity 40\%, Emexspinosa,X Field capacity 40\%, Ambrosia dumosa X Field capacity 100\%,

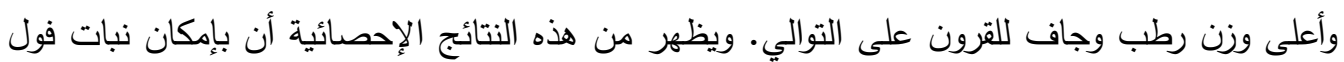

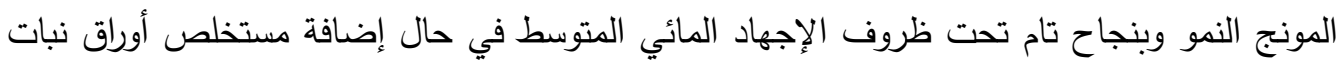
الـ Dianella ensata

الكلمات الدالة: مستخلص النباتات، الأليلوباثي، فول المونج، الجفاف، دانيلا انساتا، النباتات 
